\title{
Epistemic Roots, Universal Routes and Ontological Roofs of African "Ritual Archives": Disciplinary Formations in African Thought
}

\author{
Oluwatoyin Vincent Adepoju \\ Comparative Cognitive Processes and Systems (Compcros) \\ http://danteadinkra.wixsite.com/compcros \\ toyin.adepoju@gmail.com
}

\section{Introduction: Why Write an Essay on an Essay?}

One may compose an essay on another essay, and possibly an even longer one than the essay being studied, long as that one is, when one is confronted with one of those things one has to say something about after encountering them. "Ritual Archives", the climatic conclusion of the account in The Toyin Falola Reader ( Austin: Pan African University, 2018), of the efforts of Africa and its Americas Diaspora to achieve political, economic, intellectual and cultural individuality, is a deeply intriguing, ideationally, structurally and stylistically powerful and inspiring work, rich with ideas and arresting verbal and visual images. His focus is Africa and its Diaspora, but his thought resonates with implications far beyond Africa, into contexts of struggle for plurality of vision outside and even within the West, the global dominance of whose central theoretical constructs inspires Falola's essay.

"Ritual Archives", oscillates between the analytical and the poetic, the ruminative and the architectonic, expressive styles pouring out a wealth of ideas, which, even though adequately integrated, are not always adequately elaborated on. This essay responds to the resonance of those ideas, further illuminating their intrinsic semantic values and demonstrating my perception of the intersections of the concerns they express with issues beyond the African referent of "Ritual Archives". This response is organized in five parts, representing my understanding of the five major thematic strategies through which the central idea is laid out and expanded. 
The first section, "Developing Classical African Expressions as Sources of Locally and Universally Valid Theory" explores Falola's advocacy for an expanded cultivation of theory from Africa created and Africa inspired expressive forms. "Epistemic and Metaphysical Integrity in Ifá", the second part, examines his argument for a re-centering of studies in classical African thought within the epistemic and metaphysical frames of those bodies of knowledge, using the Yoruba origin Ifá system of knowledge, spiritual development and divination as an example, an illustration I analyze through my own understanding of the cognitive and metaphysical framework of Ifá. The third unit, "Falola's Image Theory and Praxis, Image as Archive, Image as Initiator", demonstrates Falola's dramatization of the cognitive possibilities of works of art as inspirers of theory, exemplified by a figurine of the Yoruba origin orișà cosmology, the deity Esu. This is the most poetic and one of the most imaginatively, ideationally evocative and yet tantalizingly inadequately elaborated sections of "Ritual Archives", evoking continuities between Yoruba philosophy, òrișà cosmology and various bodies of knowledge across art and image theory and history, without expanding on the ideas or building them into a structure adequately responsive to the promise of the ideas projected, a foundation I contribute to developing by elucidating my understanding of the significance of the ideas and their consonance with related conceptions and issues from Asian, Western and African cultures. I also demonstrate how this section may contribute to clarification of the nature of Yoruba philosophy understood as a body of ideas on the scope of human intelligibility and the relationship between that philosophy and òrișà cosmology, an expansive view of the cosmos developed in relation to the philosophy. This is a heuristic rather than an attempt at a definitive distinction and is derived from the relationship between my practical and theoretical investigation of Yoruba epistemology and Falola's exploration, in "Ritual Archives", of a particularly strategic aspect of òrisà cosmology represented by Esu. The distinction I advance between Yoruba philosophy and òișà cosmology and the effort to map their interrelations is useful in categorizing and critically analyzing various postulates that constitute classical Yoruba thought. This mapping of convergence and divergence contributes to working out the continuum in Yoruba thought between a critical and experiential configuration and a belief system. The fourth section, “The Institutional Imperative”, discusses Falola's careful working out of the institutional implications of the approach he advocates of developing locally and universally illuminating theory out of endogenous African cultural forms. The fifth part, "Imagistic Resonance", presents Falola's effort to make the Toyin Falola Reader into a ritual archive, illustrating his vision for African art as an inspirer of theory, by spacing powerful black and white pictures of forms of this art, mainly sculptural but also forms of 
clothing, largely Yoruba but also including examples from other African cultures, throughout the book.

Except for the set of images in the appendix, these artistic works are not identified, nor does the identification of those in the appendix go beyond naming them, exclusions perhaps motivated by the need to avoid expanding an already unusually big book of about 1,032 pages of central text. I reproduce and identify a number of these artistic forms and briefly elaborate on their aesthetic force and ideational power, clarifying the theoretical formations in which they are embedded and exploring the insights they could contribute to theory beyond their originating cultures. "Ritual Archives" is particularly important for me because it elucidates views strategic to my own cognitive explorations and way of life but which I have not been able to articulate with the ideational comprehensiveness and analytical penetration Falola brings to the subject of developing theory from endogenous African cultural expressions, exemplified by Ifá and art, two of my favorite subjects.

\section{Part 1 \\ Developing Classical African Expressions as Sources of Locally and Universally Valid Theory}

In "Ritual Archives" Falola is agonizing over and passionately projecting a corrective to what he rightly describes as the paucity of strategies of scholarly investigation developed from classical African cosmologies and their correlative visual, verbal and performative arts and sciences. He examines how scholarly activism has enabled, among other Africa centered configurations of knowledge, the study of classical African history and historiography, African literature and African philosophy within the globally dominant Western academic system, as well as contribute to the study and creation of new kinds of these Africa focused creative structures. He then proceeds to argue in "Pluriversalism" and "Ritual Archives", the concluding essays in the book, in a climatic section titled "Epistemologies and Ontologies", that the struggle to adequately acknowledge the potency of Africa centered forms of knowledge must go beyond their study and even their creation to include the development of theories of local and universally illuminating power from these cognitive forms.

He argues for African art in general, and its cosmological images in particular, as capable of inspiring theories that could have value for both their originating cultures and for the world at large. He pursues this argument through a description of the problem in relation to its solution, discussing that solution through general elaboration and specific examples of what he describes as "ritual archives", the cultural complexes, embracing and extending beyond 
conventionally accessible forms of being, created by engagement with the cosmos in its most expansive understanding by humanity, integrating the wonder and veneration represented by ritual and the critical thought enabling the order and continuity demonstrated by the organization of knowledge that constitutes an archive. Falola's general summations of the concept of ritual archives is lyrically compelling

...the metaphorical and mystical sense of 'archive'... that dimension of archive that is never (fully) collected but retains power and agency in invisible ways" (913). By ritual archives, I mean the conglomeration of words as well as texts, ideas, symbols, shrines, images, performances, and indeed objects that document as well as speak to those religious experiences and practices that allow us to understand the African world through various bodies of philosophies, literatures, languages, histories and much more.

By implication, ritual archives are huge, unbounded in scale and scope, storing tremendous amounts of data on both natural and supernatural agents, ancestors, gods, good and bad witches, life, death, festivals, and the interactions between the spiritual realms and earth-based human beings. To a large extent, ritual archives constitute and shape knowledge about the visible and invisible world (or what I refer to as the "non-world"), coupled with forces that breathe and are breathless, as well as secular and non-secular, with destinies, and within cities, kingships, medicine, environment, sciences and technologies. Above all, they contain shelves on sacrifices and shrines, names, places, incantations, invocations, and the entire cosmos of all the deities and their living subjects among human and nonhuman species (913).

...the epistemological and ideological significance of these archives [constitutes] a body of knowledge on a wide range of issues, including but not limited to cultural cognition, ideas and idea formation, semiotics, and education. Space does not permit the elaboration of the depth and breadth of the archives or the density of each genre with its own hydra-headed fragments and hundreds of individual constructions and presentations (919).

Falola illustrates these ritual archives through descriptions drawn from his native Yoruba cosmology. Central to his exemplifications are the multi-disciplinary scope, spanning the arts and mathematics, of Ifá and the figure of the deity Esu, who may be described as an embodiment of the contraries that define existence and their unificatory potential in relation to the dynamism of being, a dramatization of tension and aspiration for resolution evoked by the 
understanding of Esu as both trickster and privileged mediator of ase, a cosmic force that enables being and becoming, existence and change, individuality of being and connection between diverse forms of existence.

\section{Theory as Cognitive Imperative}

Why is Falola emphasizing the need to develop theories inspired by these classical African cultural forms? He may be seen as doing so because the ultimate bastion of the epistemic robustness of a tradition of enquiry, its vigor in terms of approaches to understanding the universe, is in its theories, the ideational lenses, the bodies of ideas on the nature of knowledge, and how it may be perceived, that underlie the cognitive activity of that tradition.

Theories are lenses through which phenomena are perceived. They are coherent ideational structures through which aspects of existence are interpreted. They are descriptions of the manner in which particular forms of being are understood, explanations of why they are seen that way as well as the logic of how these constituents of existence cohere to constitute an intelligible universe as perceived from the standpoint of a discipline, or, more broadly, from the vantage point of the epistemic universe constituted by a particular scholarly tradition embracing a totality of disciplines. Theories therefore represent the foundations of critical study of any phenomenon and of how phenomena cohere to constitute the cosmos.

This explanation of theory is based on the idea that all understanding is made possible by the relationships between the perceiving subject, particularly their cognitive faculties at play in particular perceptual contexts, the process of reaching understanding and the character of what is understood. This description adapts a triadic configuration derived from the Srividya and Trika schools of Indian thought, although the basic idea resonates across Western and Asian philosophies and what I know so far about African ideations. Theories demonstrate a process of understanding in terms of how they configure what is understood. This process demonstrates particular ideas about why the person undergoing the process of understanding is able to gain such understanding in the first place.

How do you know what you know? Why do you describe what you know the way you do? Why do you give the value you do to what you know and how many others assess the validity of your views? Those are the central questions of the philosophical discipline of epistemology and the ultimate orientation of theory. To adapt the summation of the article on theology in the Encyclopaedia Britannica 1971 on theology as a reflection on the rationale, structure and implications of religious faith, that the only alternative to theology is bad 
theology, the only alternative to theory is uncritical theory, an unacknowledged and unexamined body of assumptions shaping how people think.

\section{Roots or Foundations, Roofs and Routes of Knowledge}

Theories are the roots of scholarship. The roots are the theories, the trunk and branches the particular phenomena explored, although this image is to some degree simplistic, since the relationship between theory and what is theorized about could be quite intimate. The house of learning making up a scholarly tradition is constituted by many rooms or disciplines. These rooms, however, are built on a foundation representing conceptions of how knowledge may be developed and assessed, an epistemology, as well as a general view of the nature of the cosmos arising from this view of the nature of the intelligible, a cosmology. Each room, in turn, is covered by a ceiling representing the world as seen from the view of a particular discipline. All the rooms are in turn enclosed by a larger ceiling that projects how the universe may be perceived from the combination of the rooms that make up that house. The nature of the house is shaped by the character of its foundations, by the structure and contents of the rooms, the construction of their individual, smaller roofs and of the larger roof covering the entire house. The characteristics of these forms are fashioned through a combination of chance and choice enabled by the convergence of accidental history and deliberate historical structuring through informed decisions by various actors, circumstances not identical within various traditions of enquiry within the same cultures and between different cultures.

Thus, the Western esoteric tradition overlaps with but is different from the mainstream Western tradition of learning. Classical African and classical Western thought are different from each other and both differ from classical Asian thought, though all human forms of enquiry share significant convergences arising from the biological and environmental similarities that define the human race, as well as on account of historical intersections, routes of development between these pathways of enquiry. Roots or foundations, roofs and routes of knowledge, adapting Toyin Falola's development of this motif in the Reader as summing up the complex unity of African experience, and which I elaborate on in "Roots, Routes and Roofs: Images of Dynamic Unity at the Convergence of Personal and Cosmic History", correlative with Michel Foucault's conception of the episteme (2002) and Thomas Kuhn's theory of paradigms ( 1962), may be seen as paradigmatic or illustrative of the strategic significance of theory at the foundations and roofs of cognitive disciplines and the perceptions they enable of the world from within the complex of knowledge built within their compass. Theories are thus strategic 
within the overarching perspective on existence constituted by the superordinate scholarly tradition to which they belong, traditions created through shared epistemic and metaphysical conceptions developed through inter-referentiality, thinkers building on and referencing the work of other thinkers in developing a cognitive network within and between disciplines.

\section{Combating Hegemonies of Theory}

Why must the dominant lenses, the overriding perceptual structures, the roots and roofs of knowledge, almost the only ideational systems for studying phenomena across the world, be imported from only one part of the globe, the West-Europe and its North American diaspora? That is the question Falola, along with other activists over the decades in the struggle for epistemic decolonization, are asking. Political and economic decolonization from the West has been achieved up to a point. It is also vital to pursue to its full conclusion epistemic decolonization, developing independence of cognitive frames, of ways of knowing, cultivating self-government of the mind, building original ways of exploring the cosmos and of interpreting what is discovered.

Falola decries the epistemic marginalization of the cultural forms of classical African civilizations as these creative constructions may constitute strategies of scholarly knowledge, means of developing understanding within and beyond their own cultural contexts, rather than remaining only subjects of investigation, recipients of exploratory attention from other epistemic configurations rather than drivers of investigation from within their own epistemic nuclei.

He is particularly challenged by the need to develop theories of the nature of reality inspired by classical African cosmologies and their myriad projections because he holds that not only could such constructions yield new insights about the possibilities of existence, they would liberate Africans from living as one sided consumers of theories generated by the West.

He urges freedom from the orientation of Western scholarship towards treating as universal the locality of its knowledge grounded in study of what is native to its own environment, while other natalities, other nativistic contexts, remain localized. Thus an uncritical universalism is developed. In place of that, he advocates a critical universalism, a measured appreciation of the degree to which a body of knowledge, necessarily derived from an environment, can illuminate both that environment and other phenomena outside of its own context, a reflexive universalism he names "pluriversalism", to suggest the creation of plural, multiple, co-existing centers of universal value. 
"Ritual Archives" reminds me of Wole Soyinka's great essay collection, Myth, Literature and the African World. Along with Falola's "Pluriversalism" also in the Reader, "Ritual Archives" may be seen as taking forward the broad outlines of the project articulated by Soyinka, a project progressively actualized over the years before and since the first publications of the Soyinka essays and their collection in book form, by artists, and to some degree, scholars, inspired by classical African cultures. What Falola is doing in "Ritual Archives" is taking forward the urging of Soyinka for engagement with the spiritual and ideational power of classical African cultures as exemplified by his native Yoruba civilization.

Falola is advocating, not only for such an engagement, a possibility already richly realized across a broad spectrum of creative endeavor, but even more specifically, for the development of theories inspired by these cosmological systems and their expressive forms. Like Soyinka, his examples are drawn from the classical cosmology of the Yoruba civilization common to them both, their style of writing suggesting an identification with this cosmology and its creative expressions, an identification beyond the purely imaginative, evoking these inventive structures as constituting aspects of the core of the meaning of existence for these scholars. Whatever the quality of insight the theories developed in Western contexts deliver, should the modulations of perception enabled by their construction in distinctive conditions not be factored into evaluations of their significance and how they are adopted? Rather than depending on theory from one cultural source, should each cultural setting not create its own theories, and, keeping in mind the manner in which each social context shapes cognitive creation, use these theories in interpreting both its own context and contexts beyond itself, giving room for local influences in its own theory construction as well as commonalities within differences shared by human beings?

Falola is focusing, therefore, not so much on the study of African subjects, but on the development of ways of exploration, modes of cognition, styles of thought, from within Africa centered creations and the projection of these cognitive matrices beyond their originating contexts, thus enabling the interpretation of other phenomena beyond the cultural roots that give birth to these theories, thereby expanding the universe of ways of knowing and perhaps even of organizing and applying knowledge available to humanity. Thereby, African or African inspired cognitive spaces would also export ways of creating knowledge instead of being focused only on importation of such engines of mental creation into their own creative spaces. Other geographies of knowledge would then have the opportunity of importing African cognitive engines, theories significantly inspired by cognitive pathways native to 
Africans' journeys of understanding. Thus a global cross-current of creative strategies would be developed in relation to Africa.

Such a picture goes beyond the current situation in which Africa's cognitive network is shaped principally by ideas on how to develop knowledge imported from Western scholarship, even when the subject of study is African. As Falola elaborates on in the Reader, a lot of progress has been made, for example, in integrating African oral methods of recording history into the study of African history, a strategy Jan Vansina (1965), among other scholars, is notable in working out. Falola is arguing, not only for the expansion of this adoption of ways of knowing endogenous to Africa in the study of various disciplines, but for the application of such epistemic systems, adopted in their native forms or reworked as may be necessary, in the study of a range of phenomena within and beyond the African context, thus expanding the capacity of illumination enabled by African or African inspired systems of knowledge.

The essay, like his ideationally scintillating and passionately profound "Pluriversalism" represents for me the shock of encountering ideas I have long lived by but have not been able to express in the comprehensive summativeness that Falola dramatizes in these writings. "Ritual Archives" also powerfully foregrounds a situation beyond the geographical and social contexts which Falola concentrates on in the piece. Falola's inspiration and focus is Africa, but his ideas are relevant beyond Africa, being vital for the very Western civilization whose scholarship has been the creators of the marginalization of African expressive forms he agonizes over, as well as for Asian, South American and Aboriginal Australian cultures, among other cognitive worlds marginalized in the epistemic and metaphysical frames through which knowledge is reached in the Western academy in its global dominance.

I get the impression that Falola's challenge resonates most penetratingly in relation to what may be described as a particular epistemic frame privileged in Western culture and upheld in its global dominance, which may be descried as a cognitive mentality centered in privileging the ratiocinative and the logocentric, linear thought and its expression in language, rather than a related centralizing of the power of the senses, for example, as sources of authoritative knowledge. As has been pointed out, though, by Kwame Bediako in his essay on African theology in David Fordes' edited The Modern Theologians: An Introduction to Christian Theology in the Twentieth Century, being the 1997, second edition, different from the third 2005 edition, The Modern Theologians: An Introduction to Christian Theology Since 1918, where Bedaiko's essay on African theology is replaced by that by Tinyiko Sam Maluleke, even the West has suffered a similar suppression in terms of its pre-Christian heritage, which enthusiasts are struggling to recover and revalidate. Western esotericism has itself been supplanted by what may be seen as an Enlightenment 
derived emphasis on the ratiocinative and secular, leaving the older culture marginalized in the marketplace of scholarly knowledge, marginalization evident wherever the West has planted its dominant cognitive culture, often through colonization.

The damage is less in places like India, on account of its rich culture of classical texts, among other factors, but to what degree do these classical cognitive systems shape the official culture of learning even in that subcontinent? In what way is the dominant academic culture of India different from that evident in New York and London? Is the emulation of the global metropolises represented by the West not the organizational norm and general aspiration world-wide? Falola advocates the increased recognition of the vitality of classical African religious systems, their ritual structures and the material forms associated with them as primary knowledge generators. He expounds forcefully on these ritual archives as evidence of ways of knowing vital to investigate in order to grasp the full scope of the cognitive possibilities humanity has been able to develop. He analyses compellingly the epistemic subjugation created by colonialism in Africa in the marginalization of African and particularly classical Nigerian religious cosmologies and their ritual archives. Why the emphasis on religion and its expressions, in a world dominated by the secular power of science, scientific culture being one of the greatest limitations of Africa? Falola states:

In varied ways, a countless number of sages, priests, devotees and practitioners created oral and visual libraries, which are linked to ritual complexes and secular palaces. Subsequently, cultural knowledge has extended from the deep past to our present day. It is through their knowledge that histories and traditions were constituted, while identities were formed, and philosophy as we know it emerged....In the process, the traditions in ritual archives provide some templates for the future; the contents of the archives become the philosophy, literature, and history; their interpretations become manifested in our present as part of our engagement with heritage and modernity (914).

While Falola might have been referring purely or primarily to Africa, he is also summing up what I understand as the current stage of scholarship on the roots of Western philosophy and science. Religion and its related ideas and practices constitute humanity's oldest and most deeply rooted modes of making meaning of the cosmos and thus constitute the historical and ultimate ideational foundations of a good degree of human activity, particularly its cognitive creations. 
Hence, the roots of Western philosophy are described as being in Greece and the first exploration in that tradition of the nature of being, the fact of existence, a central subject in philosophy, is described as carried out by the Greek thinker Parmenides in the context of a discussion with a goddess ( Herman, 139-213).

The first great scientist in Western thought was Aristotle and all his investigations, spanning several disciplines across what later became known as the humanities, social sciences and sciences, are driving towards a goal he sets out in the Metaphysics, an effort to grasp the underlying principles of phenomena and thereby reach into the mind of the ultimate creative intelligence, as described by Jonathan Lear in Aristotle: The Desire to Understand, an aspiration also resonant in 20th-21st century scientist Stephen Hawking's summation of the ultimate goal of physics in his A Brief History of Time.

This aspiration also reaches back to the dawn of modern science in the representative text of the17th century Scientific Revolution, Isaac Newton's Mathematical Principles of Natural Philosophy, the concluding section of which caps his development of the theory of gravity and the laws of motion in which he worked out relationships between particular phenomena and universal principles. In that conclusion, Newton paints a majestic picture of the being of God in relation to his own enquiries into space and time across terrestrial and celestial scales, that divine image being a primary inspiration of his quest, having spent as much, if not even more time, on religious and occult investigations as on scientific study.

Recognizing the complex multidisciplinarity of his thought as embracing in mutual fecundation disciplines now understood as epistemologically distinctive, contemporary Newton scholarship elaborates on the links between his science and his Christian and occult explorations. Richard Westfall's Never at Rest: A Biography of Isaac Newton and his superb distillation of his research in the 1992 Encyclopaedia Britannica are definitive examples of this scholarship, while Rob Illfe's Newton: A Very Short Introduction, sums up the field up till the digitization of Newton's work in the occult, quasi-scientific discipline of alchemy.

If Falola is summing up an idea already well known in the histories of Western philosophy and of science, what is its place in an essay on epistemic decolonization in African inspired thought? The struggle to validate the contemporary and future creative possibilities of classical African thought remains live. The varied richness at the base of Western thought is not well known, and thus, the rationality of modern Western thought can be juxtaposed against what is described as the problematic rationality of classical African thought. Scholars like Falola and Abiola Irele, for example, as in Irele's "The African Scholar", reframe African thought by pointing out the varied 
possibilities of its classical heritage, urging it be developed in terms of multiple but ultimately interrelated epistemic and disciplinary possibilities as the West has developed its own cognitive legacy. Falola sums up this vision:

Finally, the tail end of my assertions will suggest transformational strategies in according a critical place for ritual archives ... to formulate evaluation mechanisms to authenticate indigenous knowledge and those who communicate them using data-driven and emic standards. At all levels of the educational system, indigenous ways of knowing, along with the knowledge and researchers of those accumulated knowledges must be fully blended with the Western academy (916).

How is this blending to be achieved? By grafting the hitherto marginalized classical African cognitions onto the dominant Western system? No. Falola is projecting something more radical, a rethinking of the classical African corpus from within its own epistemic and ontological foundations. The reflexive process he advocates would work out these systems' distinctive understandings of the nature and process of perception and of the nature of being thus perceived as well as how these insights can be relevant to the present beyond their originating contexts, as insights valid for humanity as a whole. This task is described in a passage rich in ideational grace and power, compelling in its rhetorical rhythm, its force of commitment and its visionary concreteness:

Ritual archives tell us that we must review and question our externally derived approaches and the limitations of the methodologies we deploy. Western-derived disciplines (such as Religious Studies, History, and Philosophy as subjects of the Humanities) have carefully fragmented ritual archives, but it is time for all those disciplines to combine to provide an understanding of the centers of indigenous epistemologies, to unify their ontologies, and convert them to theories that will be treated as universal (916).

The visionary character of this passage emerges from its imaginative projection into the centres of possibility of cognitive systems whose nature is inadequately understood, like a glimpse of the majesty of the sky at night, the constellations ablaze as distant points of light within dark depths suggesting the compelling mystery of the largely unknown cosmos, that image a celestial analogue to Falola's evocation of strategies of knowledge which the writer is certain would achieve greater robustness if their various units are creatively conjoined.

The rhetorical music of the lines comes from the writer's movement from pointing out a challenge of scholarship, describing its origins and concluding 
in presenting a solution to the problem represented by the challenge. This ideational progression is made memorable by diction chosen for precision and semantic range, set like gemstones within carefully woven syntactic structures. The concreteness of the passage is demonstrated in its identification of the disciplinary contexts and procedures to be employed in achieving the goal the text advocates.

\section{Part 2 \\ Epistemic and Metaphysical Integrity in Ifá}

What unusual ways of knowing, what unconventional epistemologies, may emerge from the reformulations Falola is suggesting? Could these lead to novel perceptions of the nature of phenomena, and of the place of such phenomena within the network constituting the totality of possibility? Could fresh conceptions of the potential of human understanding emerge through these reconstructions? Falola exemplifies this idea of disciplinary reconstruction by referencing the Yoruba origin Ifá system of knowledge, spiritual discipline and divination:

Experts work around each component, so that a scholar can study Ifá in various departments-Philosophy, Music, Drama, Literature, Linguistics, Religious Studies, Government, Sociology, Art, Anthropology, and History. In each of the disciplines, Ifá may become disconnected from the multilayered and intricately connected indigenous epistemology that produces it in favor of the concerns of the disciplines framed from other epistemologies external to the indigenous. In this regard, Ifá has been disembodied and fragmented. The questions posed can become "external" to its own organic make up, for example, whether Ifá is a philosophy or religion. Are incantations magical texts or creative literary texts? If Ifá verses are originally recited orally, what happens when they become printed texts? Do the printed texts, when read, become as effective as divination? (918).

These are very rich questions, foregrounding the question of the logic of disciplinary characterizations. These questions also project enquiry on the relationships between different kinds of textuality. An adequate response to such queries can only be arrived at or even approached through an examination of comparative modes of knowing and of understanding forms of existence, as these investigations are conducted in relation to Ifá. Such understanding may be developed in terms of the logic of the institutionalizing of knowledge developed within particular cultures. The dominance of one such culture, the West, may give the impression of the unassailable logic of 
the disciplinary characterizations cultivated in this culture. The characterization and organization of disciplines, however, as demonstrated by Michel Foucault in The Order of Things and Madness and Civilisation, among other texts, are now generally understood as shaped by circumstances incidental to the distinctive epistemic histories of various cultures. Along such lines, as understanding has grown of a plurality of approaches to critical knowledge, credence is given, even within Western scholarship, to contrastive ways of understanding the nature of philosophy, an accomodationist stance beautifully demonstrated by Edward Craig's Philosophy: A Very Short Introduction.

Biodun Jeyifo, in "Abiola Irele: The Scholar as Critic", describes Irele's "In Praise of Alienation" as open to interpretation in terms of Gaston Bachelard's and Louise Althusser's conception of an "epistemological break", an idea of dialectical progression in the social development of knowledge, in the "forward movement of culture and thought throughout history": "By this reasoning, every culture and society has to break fundamentally with accustomed modes of thought, with received traditions of the organisation of knowledge for it to experience historical advance to a higher, more humane stage of development".

This perspective suggests that the post-classical African experience may be better appreciated, not in terms purely of a disruption of the endogenous integrity of African cognitive systems, not only in terms of their fragmentation by the colonial encounter. It may be more fully grasped in terms of an expansion of possibility enabled by the colonial experience.

The epistemic violence of the colonial encounter may be seen as facilitating in classical African thought a greater openness as before to possibilities different from those of its native cultural range. Within this expansiveness, the student of Ifá, for example, may recognize its affinities with the Greek understanding of philo-sophia, the love of wisdom, but also recognize its differences from the ratiocinative character of the Aristotelian formulation of philosophy and the dialogical critiques of Plato as well as the dialogical Tantric tradition of India, while recognizing its affinity with the parabolic and mythic constructions of Platonic and Indian thought. These conjunctions and divergences could be appreciated in the context of exploring various forms of rationality, linear, non-linear and imaginative, among others significant in Ifá, examining how the varied expressions of these rationalities may enrich each other.

In this style of thinking, the emphasis is on the recognition of the fragmentation decried by Falola as better appreciated as a stage in a creative progression. This progression demonstrates the expansion of the creative potential of Ifá through encounter with various points of emphases within the scope of human rationality. The intrinsic possibilities of the endogenous character 
of Ifá may thus be expanded through this extrinsic exploration. In that sense, Falola's goal of re-validating African ritual archives and fully blending them with the Western academy would be achieved, transforming the negativities of Western imperialism into an ultimately creative outcome for those outside the West and the West itself.

From an original endogenous unity to a fragmentation through insertion within an externally developed cognitive system, the endogenous may then move towards another self-generated integration by drawing the lessons gained from the external encounter within its own circle of knowledge, thus reaching the stage so described by Falola:

Texts, as in the case of ese ifá chants, taken out of odù ifá, are entry points to the understanding of history, philosophy and literature, grounded in the epistemologies of cosmology and mythology. But the cosmology and mythology cannot operate without forms of rationality, as they need to explain other issues such as medicine, politics, and critical appreciation (918).

In those lines, Falola may be seen as working out a reintegration of Ifá. He can be understood as moving from the fragmentation of Ifá under the impact of Western forms of disciplinary organization to a reintegration using those same forms but in terms of an orientation derived from the epistemological implications of the cosmological core of Ifá, as this cosmological centre operates through mythic discourse.

What is the nature of this epistemology? What kind of rationality/ies does it demonstrate? How may these forms of rationality impact on the holistic exploration of Ifá as well as on the study of its various component disciplines an $\mathrm{d}$ of those disciplines to which Ifá might be seen as having a more distant relationship? What may be seen as the ultimate possibilities of these explorations?

A cosmology may be perceived as implying a relationship between the person constructing that cosmology and the cosmos the cosmology interprets. This relationship is constructed through the structure of ideas represented by that cosmology. The cosmology is thus an interface, an interpretive matrix, between the human being and the world beyond themselves which they try to comprehend through this structure of ideas.

This understanding of the relationship between cosmology and epistemology is based on the idea that all understanding is made possible by the connections between the perceiving subject, represented by their cognitive faculties, the process of reaching understanding and the character of what is understood. This description adapts a triadic configuration derived from the Srividya and Trika schools of Indian thought, although the basic idea 
resonates across Western and Asian philosophies and what I know so far about African ideations.

What may be perceived as the central ideas on the nature of the human being in Ifá, on the character of the cosmos and the relationship between these two units in the scale of the larger framework represented by the cosmos and one of its units, the human being? The conception of the Babaláwo, which may be translated as "adept in the esoteric knowledge of Ifá", a crowning grade of development in traditional Ifá practice, could act as a guide in answering these questions.

The following elaboration on the concept of the Babaláwo comes from my response to a 30th October 2017 Facebook post by humanities scholar Adeleke Adeeko. His description of Ifá in our exchange emphasizes its humanistic thrust and multidisciplinary integration, while my response insists on the need to recognize the grounding of that multidisciplinary dynamic in particular cosmological conceptions. Countering my interpretation of the concept of the Babaláwo, Adeeko responds that:

It is more profitable in scholarly contexts, I believe, to take "awo" to mean laborious, high learning and knowing (imọ), so valuable and specialized that it requires years of commitment and elaborate certification. The esoteric part of Ifá ... does not appeal to me so much as its accessible poetry of knowledge coding, its grounds of knowing and disclosure, its centering fecund interpretation, its privileging of the client. I am completely convinced that láisí èniyàn, imalè kò sí (without humanity, divinity is not).

I engage with Adeeko's response using his analytical categories as a springboard:

Babalawo" may be described as "adept in the esoteric knowledge of Ifá," integrating a metaphorical interpretation of male elderhood in the word "baba" and a metaphysical principle in the concept "awo". The Yoruba word "baba" operates at a scale ranging from the literal to the metaphorical. In literal terms, it refers to fatherhood. Metaphorically, it signifies a male eld er. At a further metaphoric level, it may also be adapted to refer to the conjunction of the venerable and the authoritativethat comes with mastery of a discipline. Thus, I render it as "adept" in translating the term "babalawo. "' "Awo" refers to esoteric knowledge, spiritual mystery, also adapted in colloquial contexts to mean something secret.

The term awo also occurs in contexts that do not require "laborious, high learning and knowing, so valuable and specialized that it requires years of 
commitment and elaborate certification" an impressive summation of the institutional framing of the Babalawo concept as a crowning grade of development in traditional Ifá practice, but which might not be as valid for other forms of spirituality and magic that do not necessarily demonstrate the pedagogic rigor associated with Ifá. Thus, awo may refer to any form of esoteric spiritual knowledge and activity, but not necessarily in relation to Ifá. Within the term Babalawo, however, awo becomes specific to Ifá. Awo Fa'lokun Fatunmbi in "Obatala: Ifá and the Chief of the Spirit of the White Cloth", describes awo as:

...a body of wisdom...which attempts to preserve the rituals that create direct communication with forces in Nature. [It] refers to the hidden principles that explain the Mystery of Creation and Evolution. Awo is the esoteric understanding of the invisible forces that sustain dynamics and form within Nature. The essence of these forces are not considered secret because they are devious, they are secret because they remain elusive, awesome in their power to transform and not readily apparent. As such they can only be grasped through direct interaction and participation. Anything which can be known by the intellect alone ceases to be awo.

Aina Olomo in a post of 3rd August 2010 on the Yoruba Affairs Google group, under the thread "Esoteric Knowledge and Power in the Orisa Tradition", also defines awo as :

the inexplicable power of transformation. It is stored in the mystical dimension of Awo; it is a realm of phenomena that is unavailable for total absorption by the human mind. Its power carries out actions initiated by the cosmic consciousness of the Infinite Mystery or Source and then manifests that power in the three dimensional world of humanity. The realm of Awo is a parallel world without boundaries, constantly regenerating, expanding its breadth and depth; this is the dimension of consciousness where the sum total of humanity's inspirations and experiences are alive, existing forever in the minutes of today, never solely attentive or restricted to yesterday or tomorrow. This power brings everything in the Universe into existence. Its apparatus is dialectical, creating harmony- dysfunction, joy - sadness, awareness - unconsciousness, and matter - thought, light darkness, as they co-exist in the consciousness of Source simultaneously. Awo is the space in the universe where the illusive answer to how dwells. Awo is inexhaustible because of its closeness to the ultimate and Supreme Being, the Infinite Mystery. 
The concept of awo may be clarified with reference to the Christian concept of mystery and philosopher of religion Rudolph Otto's idea of the numinous developed in his The Idea of the Holy. Webster's Third New International Dictionary (1966) defines the numinous as "an invisible but majestic presence that inspires both dread and fascination and constitutes the non-rational element in vital religion".

Mystery in the Christian context does not refer simply to what the Catholic theologian Karl Rahner describes as "the unfortunate remainder of what is not yet known" in "Living into Mystery: Karl Rahner's Reflections on his 75th Birthday". In Rahner's words in the same interview:

The true system of thought [in theology] really is the knowledge that humanity is finally directed precisely not toward what it can control in knowledge but toward the absolute mystery as such; that mystery is not just an unfortunate remainder of what is not yet known but rather the blessed goal of knowledge which comes to itself when it is with the incomprehensible One... With other words, then, the system [of my theology] is the system of what cannot be systematized.

Rahner thus suggests a zone of being that transcends human efforts to encapsulate it in knowledge and yet is accessible to the human person. The image of Kaidara as described by Ahmadou Hampate Ba in Kaidara: A Fulani Cosmological Epic from Mali, evokes such conceptions of relationship between presence and distance in the context of the scope and limits of the knowable in the figure of a decrepit and dirty old man who is yet a beam of light from the hearth of Gueno, creator of the universe, a disguise created to test, among people he encounters in his peregrinations around the world, their readiness to receive the knowledge he embodies of the ultimate possibilities of human understanding.

The awo in Babalawo may be seen in a similar context as evoking the sense of an inscrutable mystery, potent but opaque, mysterious but dynamic, compelling in its distance from conventional human grasp but active in various situations. On Ifá as a literary and epistemic system, beautifully summed up by Adeeko in terms of "its accessible poetry of knowledge coding, its grounds of knowing and disclosure, its centering fecund interpretation, its privileging of the client", it is Ifá's grounding in an esoteric core that validates all those configurations. What are the grounds of knowing and disclosure in Ifá? Is it limited to interpreting its symbolic forms, the odù ifá, purely in terms of readily accessible information? No. The odù ifá are described, not purely as information matrices, as collections of literature, but as sentient entities in their own right, abstract identities expressed in the form of humanly created 
symbols, conceptions demonstrated by Wande Abimbola in An Exposition of Ifá Literary Corpus and Ifá Divination Poetry, in which he references oral traditions depicting the odù ifá descending to earth from òrun, the world of metaphysical origins where Olodumare, the creator of the cosmos is centered.

In a personal communication by Babalawo Joseph Ohomina, Ohomina describes the odù ifá as "spirits whose origin we do not know and of whose significance we understand only a small fraction and yet who represent the spiritual names of all possibilities of existence", a summation I discuss in "Cosmological Permutations : Joseph Ohomina's Ifá Philosophy and the Quest for the Unity of Being". Is Ifá literature, its primary means of organization and expression, limited to its evident structural and thematic values? No. That literature is mobilized in divination as a means of communicating the voice of an oracle, an intelligence described as divine, requiring supra-intellectual methods to access.

\section{Self and Cosmos in Ifá}

How does Ifá privilege the client? Simply by consulting the oracle on behalf of an enquirer? No. The consultation is understood to operate at the nexus of interaction between the primordial and yet historically grounded wisdom represented by the odì ifá and the essential identity of the client, their orí, their metaphysical head and ultimate centre of direction, the embodiment of their ultimate potential, a core of being whose cooperation or alignment with a purpose is vital for success, hence it is stated that no òrișà or deity can bless one without the consent of one's orí, the only deity who can follow its devotee on any journey, even the ultimate journey of death, since the existence of the ori is understood as preceding terrestrial birth and outliving the death of the body. Thus, while Ifá can be discussed in secular terms, it is not a secular but a spiritual discipline, rooted in conceptions in Yoruba metaphysics and epistemology that unify Yoruba philosophy and spirituality.

These conceptions provide fruitful ground for explorations at the intersection of hermeneutics, theory of interpretation, epistemology, theory of knowledge and metaphysics, theory of being, in relation to such strategic ideas in Yoruba thought as the relationship between àse, a form of cosmic force, and language as an expression of this force, among other conceptions, as I describe in "Orality and the Metaphysics of Language in Yoruba Thought", building on Rowland Abiodun's discussion, in Yoruba Art and Language: Seeking the African in African Art, of ọrọ, discourse in Yoruba philosophy, in relation to àsẹ. An adequate excavation of the ideational possibilities of Ifá is possible only by careful attention to its philosophical and spiritual grounding, relating these to any tasks the student of Ifá wishes, transposing them in secular terms or 
further developing their understanding as engagements with unconventional forms of sentience and power. Western and Asian hermeneutics have taken this route and recurrently draw more possibilities from the foundational wells located in their sacred text and their associated practices. One may wish to study Ifá purely in secular terms, but it instructive to note that in doing so, one is bracketing out one possibility out of a much larger matrix.

What may be the implications for scholarship, for critical relationship with ideas, for the view of the metaphysical core of Ifá represented by the concept of awo? What may be the significance of that idea for the study and use of ideas from Ifá, for an adaptation of them to strategies of thinking and insight, of reflection and perception? Must one identify with the awo concept to be able to use Ifá ideas in full recognition of their metaphysical ground as Falola advocates, as different from a sundering of them from their cosmological roots, a fragmentation Falola decries? I would think that what is imperative is exploration into the cosmological framework of Ifá, into its epistemic strategies and metaphysical roots, explorations which might not lead to the same conclusions by different people, as suggested, for example, by comments in the discussion on Ifá quoted by Falola in "Ritual Archives", in which Babatunde Emmanuel poses a question deriving from his interest in transposing Ifá into science, perhaps under the inspiration of its mathematical structure and its aspirations to comprehensive mapping of phenomena:

How does a religious matrix based on revelation and symbolic classification transform into an empirically validatable and refutable source of knowledge that will not depend on dogma and persecution to justify and corroborate its views as valid? Since Mathematics is the language of science because it is logic in symbols, in order to make anything scientific, it must be mathematically replicatable, refutable, and verifiable. When will Yoruba Renaissance occur that will move claims of Ifá from the realm of belief to the realm of fact? (918)

Archeologist-cum-Historian Akin Ogundiran gave an immediate answer:

Ifá is not based on revelation. It is based on learning, and its processes and outcomes can be replicated. My own field research has proven this in multiple places, over several years. Moreover, the intellectual communities from which Ifá developed are not based on dogma. ... It is based on openness of thought, critique, and experimentation.

Ifá is a corpus of different categories of knowledge, not just religion. It is also a body of knowledge on history, philosophy, etc... Computer scientists, 
such as Dr. Tunde Adegbola, are doing fascinating work that shows that "the scientific basis of Ifá is the same with the subject of simulation in Operations Research" (Adegbola).

What is important in the methodology that Dr. Adegbola is using is that he is also doing ethnographic field research in order to systematically collect the data needed for his systems analysis work. As far back as the 1990s, Oba Pichardo and his Lukumi collaborators in Miami, Florida, were able to write computer codes that allowed them to conduct computer-based Ifá divination. It was a preliminary work when I saw it around 2007. It is possible that they have expanded the work since then.

A number of scholars from different fields have started to answer these questions. What their studies are telling us is that one cannot stand outside a tradition or a system of knowledge to make declarations about that knowledge. ...Dr. Wariboko stated, Ifá offers...rich fodder for theorizing a diverse range of ontological issues. These areas will continue to be relevant. However, the area of systems and mathematical analysis offer a very fascinating path of inquiry. This effort should involve the collaboration of traditional academics, scientists, and practitioners" (919).

Olu Longe's pioneering "Ifá Divination and Computer Science", Femi Alamu et al's "A Comparative Study of Ifá Divination and Computer Science", my "Rethinking Ifá : From Classical to Post-Classical Geometries 1 : The Ifá Vectors of Moyo Okediji" take forward ideas of the scientific significance and potential of Ifá and the debate I edited "Ifá/Afa/Efa/ Fa, Science and Comparative Scholarship" examines the same subject in the context of the epistemic procedures through which the various interlocking dimensions of Ifá may best be explored. I acknowledge the full scope of Ifá as a spiritual discipline embracing a range of aspects that may be significantly deployed without reference to the spiritual centre of the system. Such fragmentation, as Falola might put it, is vital for enabling access to and use of the protean character of this broad ranging body of knowledge, a task that would be hampered if some of its more abstract philosophical and spiritual ideas cannot be bracketed out while exploring its convergence with secular thought and creativity in different disciplines. 


\section{Part 3 \\ Images as Epistemic Catalysts}

While I have been working with similar ideas in my individual bodies of work, Falola's perspective is that of a bird soaring above the creative landscape, its keen eye aggregating possibilities similar to those which I have engaged with in terms of distinctive expressions, his synthesizing intelligence transmuting the particular to the general and unfolding the general into the particular, unfurling a tapestry of numerous, interlinked possibilities, integrating potential that is then unfurled, breaking open an ideational consolidation to reveal a schematically organized universe of possibilities, a grain of sand, a tightly woven condensation of myriads, split open to reveal the cosmos, "In the heart of a minute particle of dust/is present a vast scroll/as large as the three thousand fold world/and on this scroll is recorded all things without exceptions/in this world system of three-thousand fold multi-thousand worlds", invoking an image from the Buddhist Avatamsaka Sütra (Gomez, 1995).

An exploration of the significance of developing locally and universally illuminating theory from endogenous African expressive forms as advocated by Toyin Falola in his essay "Ritual Archives". This section of the essay, along with parts 4 and 5 , are still under construction.

\section{Falola's Image Theory and Praxis: Image as Archive, Image as Initiator}

Assuming one wishes to take further an examination of Ifá or any other ritual archive on its own terms, engaging with its own epistemic grounds and their varied expressions. How may one go about it? Falola dramatizes a form of image contemplation suggesting how one may immerse oneself in the various dimensions of meaning of a ritual archive. He does this through a rich exploration of possibilities of response to a figure of the Yoruba Orisa cosmology deity, Eshu, thereby developing inspiring passages on the power of images, with particular reference to African ritual archives, building a conceptually rich, analytically incisive and deeply evocative description of the convergence of image making and sacred aspiration in classical African culture, and incidentally, across cultures, within and beyond Africa.

He thereby brings alive this classical African culture as a continuity into the present from the past in the lives of those who identify with it, in the process demonstrating how an image from Yoruba culture through which he exemplifies his image theory can provoke an engagement with the web created by the intersection of Yoruba epistemology and metaphysics. Toyin Falola's image theory and praxis thereby suggests how styles of engagement with the 
Orisa tradition, Ifá and classical African spiritual systems may be reworked. To the best of my knowledge, classical African spiritual systems are generally understood as practiced through concrete structures involving natural forms and human made objects. This is exemplified by Phyllis Galembo's ( 1998) remarkable pictures of shrines and their priests and priestesses in Benin-City by articles like Margaret Thompson and Henry John Drewal's "An Ifá Diviner's Shrine in Ijebuland" and particularly powerfully, I expect, by Robert Farris Thompson's, Face of the Gods: Art and Altars of Africa and the African Americas.

\section{Wole Soyinka at the Intersection of Physical and Contemplative Ritual}

A striking evocation of the dynamics of materially centered engagement with sacred practices in such contexts is provided by an arresting passage in Season of Anomy, a novel by Wole Soyinka, a master of ritual, classical African and self-created, an aspect of his work that lends itself to adaptation to actual ritual practice, as I point out in "Wole Soyinka's Art as a Psychological, Spiritual and Philosophical Resource" and "Contemplation as a Means of Creativity and Empowerment in the Work of Wole Soyinka : Void Meditation : Theory and Method":

In the hours before dawn the song-leaders from the dead Custodian's household followed Ahime through the sleeping town, swift dark-brushing motions of maroon loin-cloths. All paths must be trodden in the predawn hours, heads bent to the ground, acknowledging no one and seeing none. A low moan rose, thrilled in the slumbersome air, the earth gave answer in trembling accents, a lead voice prompted the sleep-washed dirge of earth and a sudden motion of feet would thud in velvety unison. The dark figures swayed backwards, leant into the yielding night-membrane, uncoiled in a python lunge upwelling into a dark toned monody. Then they leapt forward again along the path, sending soft vibrations along the path. Blood, oil, colanuts, slain pigeons at every spot where a founder had fallen, sacrificed or finally rested, at every meaning left behind by the first progenitors. The departed were appeased, venerated, welcomed, touched and brought among the living. The new deceased was on his way (12).

In Myth, Literature and the African World, a related ritual is dramatized in similar poetic terms by Soyinka: 
In cult funerals, the circle of initiate mourners, an ageless, swaying grove of dark pines, raises a chant around a mortar of fire, and words are taken back to their roots, to their original poetic sources when fusion was total and the movement of words was the very passage of music and the dance of images (147).

$\ldots$

The senses do not at such moments interpret myth in their particular concretions; we are left only with the emotional and spiritual values, the essential experience of cosmic reality. (148).

Soyinka succeeds wonderfully in developing rituals which can be used in a purely contemplative or a dramatized form, as in the ritual at the centre of Death and the King's Horseman, which may be approached as a powerful African version of the famous Tibetan Book of the Dead, described as a means of guiding people leaving the world in death to crossing the borders between earthly existence and the mysterious zones into which they are moving in this fundamental transition.

It is also comparative with the Egyptian Book of the Dead, known to me in an inspiring version titled The Book of Coming Forth by Day, death and its management being central to ancient Egyptian spirituality and architecture. It is also correlative with the work of Elisabeth Kübler-Ross on death and dying in her book of that title, as a process that needs to be theorized and mapped and the participants in the process guided through it. Tibetan Buddhism adapts this complex of ideas in the Gcod hod ritual, in which the aspirant imagines themselves in a state similar to that of death, progressively divesting themselves of the material constituents that define themselves, in order to identify with the fecund emptiness that enables existence, its voidness an expression of its transcendence of all human perceptual capacity (Orifino, 2000).

The contemplative method and thematic orientation of the Chod ritual is also correlative with another contemplation of emptiness from a different context, Soyinka's meditation on the nothingness before existence in his The Credo of Being and Nothingness. That Soyinka meditation is itself resonant with his reflections on emptiness in his prison memoir The Man Died, in terms of the infinite possibilities evoked by the inspiring emptiness of a blank sheet of paper, a luxury stirring almost metaphysical appreciation from a profound and prolific writer starved of writing material while in jail, an enforced seclusion often reinforced by his being isolated from human company in solitary confinement. 


\section{Howard Philips Lovecraft and John Milton}

I wonder to what degree this aspect of Soyinka's work is appreciated and to what degree it is used in actual contemplative or dramatic ritual practice. Adaptations of imaginative literature to serious spiritual and philosophical activity emerge in various contexts, framed by the fact that much religious and philosophical expression is imaginative.

A particularly striking example of such transitions is the religious adaptations of H.P. Lovecraft's Chthulhu mythos (The Call of Cthulhu and Other Weird Stories, The Thing on the Doorstep and Other Weird Stories, The Dreams in the Witch House and Other Weird Stories) inspired by the complex of qualities that animate his unprecedentedly unique oeuvre in which the imaginative exuberance of his characterizations and plots is brought alive by uniquely magnificent language. His universe of wonderfully characterized otherworldly entities within a gradually unfolding but never fully illuminated cosmological matrix thus contributing to its enthralling mystery, dramatizes a compelling evocation of the numinous, the tension between a compelling otherness and its distancing alienness, thus evoking the paradoxical conjunction between the human being's breadth of cognitive aspiration and the scope of human perceptual possibility

These qualities make his work fertile for counter cultural forms of mysticism, the most uncompromising of this being a form of demonic mysticism, as in the occult groups Dragon Rouge, as the group states on its website, and other enthusiasts inspired by Lovecraft's unique actualization of the impulse represented by the older example of John Milton's majestic evocations of the landscape, denizens and psychology of Hell in Paradise Lost. Milton's projection of the glorification of the infernal, however, may be better appreciated through contrast with the Hell of Dante Alighieri's Inferno, the most impactful evocation of Hell in Western literature, but purely a place of torment and regret within marvelously imagined horrors undergone by the dammed.

The Miltonic Hell and the dreadful cosmos of Lovecraft's corrosively powerful entities, however, constitute some of the world's greatest evocations of the cosmic awe that inspires and is projected by religious consciousness. Milton's and Lovecraft's creations belong to a guild of creations of masterpieces of the terrible which include Melkor, Saurun and the landscape of Mordor in The Lord of the Rings and the Silmarilon by Milton's 20th century successor J.R.R. Tolkien as well as the Dark Lord, his acolytes and the terrible worlds they inhabit within the conventional human world, the work of Tolkien's successor J. K. Rowling in her Harry Potter books. These later works resonate with Lovecraft's incomparable landscapes of metaphysical and celestial otherness intersecting with the human mind, constituting a matrix evocative of Immanuel 
Kant's juxtaposition, in his Critique of Practical Reason, of human finitude with celestial immensity in space and time in the context of the human aspiration to infinity.

\section{Toyin Falola's Exploration of the Contemplative Potential of Classical African Sacred Art}

Soyinka demonstrates the possibility of developing novel, individualistic contemplative and physical ritual from classical African cultures. He does this through his wonderful dramatizations of Yoruba spirituality and his own development of contemplative and ritual strategies distilling both this native orientation and his immersion in a global variety of cultures, from Christianity to Tibetan Buddhism to Hinduism, thus contributing to the growing globalization of Yoruba and African spiritualties, taking them beyond their traditional geographical contexts and their conventional modes of practice.

Toyin Falola, inspired by the general matrix represented by the continuity between classical and post-classical Yoruba culture, takes this initiative further through a foundational statement of an image theory derived from African art and dramatizes how this theory may be engaged with through contemplation of African sacred forms. He argues for an approach to African religious images as archives of cognitive possibility, as encodements of ideational and cognitive expansion, as stimulators of theory, ideational networks illuminating the nature of the universe or aspects of it, bodies of ideas capable of flight from within their originating cultural contexts to illuminate other social and cognitive spaces, expansive possibilities of knowing that may be unlocked through the contemplative gaze.

This idea is not new, being the foundation of the contemplation of religious images in such systems as the use of yantras in Hinduism and mandalas in Buddhism, systems that are paradigmatic for the religious deployment of images in the scope and detail of their methods of image navigation as means of mentally mapping entire cosmologies. Image scholars such as Caroline van Eck in Art, Agency and Living Presence: From the Animated Image to the Excessive Object, operate in relation to such considerations in examining what she describes as the power of artistic forms in terms that suggest a form of autonomy of the work of art in its effect on the human mind or an equality of agency between the mind and the work of art. These conceptions of agency of artistic forms suggest ideas of animism central to religious images understood in some devotional contexts as forms of deity, as with yantra theory (Khanna, 1994) or as capable of being infused by spirit as in yantra theory and forms of Western magical theory represented by the work of Dion Fortune (2000) and in classical African thought ( Waite 2016, 
In my exposure to African art, however, I am not aware of the contemplative use of religious images as a prominent practice. The traditional focus is on material images as part of a physical shrine complex in which offerings are made. In contrast to this purely physical approach to ritual is the Hindu practice, exemplified by the Sri Devi Khadgamala Stotram (2006), in which purely physical rituals, the combination of physical ritual and contemplation as well as the exclusive use of contemplation may be employed. The Khadgamala involves the navigation of the cosmos through verbal symbols projecting rich visualizations of anthropomorphic and abstract forms, to which mental rather than physical offerings are made. Thus, the movement from physical to mental ritual described by Surrendranath Dasgupta as central in the development of abstract thought in India in his History of Indian Philosophy Vol. 1 plays itself out in such rituals as the Khadgamala.

Falola's development and dramatization of a theory of religious images in "Ritual Archives" bring such strategies within the purview of classical African art and thought. He does this, however, in a manner that frees the contemplative exercise from the carefully scripted religious contexts of a ritual like the Khadgamala. This is achieved by reworking the religious element in a creatively dynamic manner through free association. The sacred sculptural form is shown as stimulating and inspiring the contemplative's knowledge of and identification with the specific values associated with the form in a particular cosmology but through the unscripted emergence of ideas within the mind under the impetus of contemplating the artistic form.

The intelligence of the contemplative thus drinks from the theological context of the work of art without being circumscribed by the religious conceptions with which the artistic work is traditionally associated. This freewheeling approach inspires intimacy of identification with the specific ideas associated with a particular artistic form complemented by the freedom to go beyond those ideas. Falola pursues this blend of conventional contemplative strategy and personalized contemplative engagement through a form of what is known in Buddhism as deity yoga and in the Western magical tradition as described in Israel Regardie's The Tree of Life: A Study in Magic, as the assumption of god form, in which devotees imaginatively identifies themselves with a deity in order to share in the qualities of that entity. Falola evokes the values associated with the Yoruba origin of orișà cosmology or deity Esu through contemplating a sculpture of the deity. This sculpture being anthropomorphic, Falola's meditation demonstrates how the image may inspire identification with a human being through conjunctions between the values associated with the humanization of the deity and the human figure.

These values demonstrate Yoruba philosophy as ascribing various perceptual significance to different organs of the body within the context of a holistic 
assessment of the totality of the self as a unified physical and non-physical entity. The non-physical, in this context, includes and extends beyond the mind as an aspect of the mortal self-conditioned by biology and terrestrial experience to include at the core of the self, an immortal centre embodying the totality of the individual's possibilities. Dialogue with that ultimate centre is the primary goal of Ifá divination and thus the nexus of Ifá's verbal, visual, spiritual and philosophical complex, as described by such scholars of Ifá as Wande Abimbola in Ifá Divination Poetry and An Exposition of Ifá Literary Corpus, an understanding reinforced for me by a conversation with Babalawo Joseph Ohomina and central to Adegboyeya Orangun's investigations of relationships between fate and free will in Yoruba thought through interviews with various Babalawo in Destiny: The Unmanifested Being.

In the succeeding paragraphs, I juxtapose a few of the Falola quotes with quotations from writers in other cultural contexts which his passages take my mind to, thereby suggesting the international and intercultural sonorities of his thought. A key reference I make is to Hindu yantra theory, geometric forms I also discuss in relation to Yoruba òrị̀à cosmology, using a rich collection of images from òrișà thought and its Ifá iconography, from Benin Olókun iconography and Hindu yantras, in "Esu to the Mahavidyas: Integrating Contraries through Ideas and Art from Òrìsà to Tantric Cosmology". The quotes are rearranged by me in a manner which might be different from the order generated by the writer, a strategy I find useful in distilling the most inspiring ideas in a text in the way I understand them. I also try to present both literal and fuller interpretations of terms Falola does not translate as well as those he translates among those Yoruba expressions he mobilizes in exemplifying his conceptions on the power of images.

The contemplative process Falola demonstrates in "Ritual Archives" is grounded in his assertion that in classical African thought, "spirituality and materiality are united". Within this unity, "Objects encode the characters of the being they represent" enabling "Ritual objects [to] supply ideas on prayers and philosophy[ building] texts on the environment [opening into] multiple worlds of charms, magic, and medicine [opening] a wide door to a large body of mythologies, stories, legends, and many sayings, short and long".

A consummate example of this in another context is the Sri Yantra, a circle containing other circles in alignment with a structure of triangles, understood to be the mathematical form of the cosmos as the manifestation of the Goddess Tripurasundari in her geometric form, complementing her material, anthropomorphic and sonic embodiments, that geometric structure being a visual landscape through which the metaphysical and material unity of the cosmos is navigated in the Sri Devi Khadgamala Stotram ritual of which the richest English version known to me is that produced by the Shakti Saddhana 
group. Yantra theory in the Srividya school centered in Tripura is elaborated, among other sources, by Renfrew Brooks' Auspicious Wisdom: The Texts and Traditions of Hindu Sakta Tantrism in South India and The Secret of the Three Cities: An Introduction to Hindu Sakta Tantrism, with Maddhu Khanna's Yantra: The Tantric Symbol of Cosmic Unity providing the best overview known to me of yantra theory in English. Through this plethora of possibilities "Multiple specializations can emerge around image theory, image critical methodologies, image anthropology, image and culture, image philosophy, perceptions and seeing, listening, silences, and image styling".

Thus, Falola declares: "Images represent mentalities, power, and strength". Gates and Faux concur, asserting, "It is impossible to think without images", quoting Aristotle in On the Soul. Falola continues:

[Some] objects actually fit into the description of an archive as a place to keep historical records, although the collection of such objects may defy categorization. Like archives, some objects are permanent records. So also are sacred groves that provide data on the past of an enduring nature. This data touches upon culture, history, and sociology. The location of an archive may be characterized as an archive itself: the grove of a ritual tree is such a place, where the tree and its location constitute a library. Documents in an archive are treated as primary sources. So also should many ritual objects be treated as such as they communicate messages that can be used to reconstruct the past and understand various ideas about the world. Images can be used to generate image theories and create extensive narratives on cultures, trans-cultures, and inter-cultures. They supply critical issues on hybridity. To carve an object is about the representation of self, history, identity, and much more. Images are philosophical expressions, connected with thought and life. Located in museums, we tend to see and appreciate them, not necessarily engage in dialogue with them (921).

Scholarship on art and agency, however, as represented by van Eck, for example, on the range of ways people relate to art in Western history, at times as if they are dealing with living beings, complexifies the meaning of "dialogue" with art. The breadth of discourse on the museum even in the secularity of Western culture, such as Carol Duncan's consideration of the relationship between museums and human consciousness in "The Art Museum as Ritual" in Donald Preziosi's The Art of Art History: A Critical Anthology, complexifies the scope of "appreciate", in relation to museum art, arguing for the museum as enabling a sense of sacred elevation, making it, incidentally, a ritual archive in the sense of Falola's use of the term. Her referencing of Germain 
Bazin, curator of the Louvre, Paris, one of the world's great cultural treasures, from his The Museum Age, is particularly telling:

[Bazin] wrote that an art museum is 'a temple where Time seems suspended'; the visitor enters it in the hope of finding one of 'those momentary cultural epiphanies' that give him 'the illusion of knowing intuitively his essence and his strengths'”. Duncan sums up various correlative references in noting that "others...have described art museums as sites which enable individuals to...move beyond the psychic constraints of mundane existence, step out of time, and attain new, larger perspectives (428).

Falola's frame of thought from where he moves to generating his own approach to the subject, therefore, is closer to that of Susanne Wenger, operating within the religious context of the Yoruba culture that is Falola's closest inspiration in African culture. Falola's opening conception and Wenger's summation in her review of Harold Courlander's Tales of Yoruba Gods and Heroes in Research in African Literatures, Vol. 7, No. 1 (Spring, 1976), pp. 74-76, focus their sensitivity to the sacrality of art within the conventional religious contexts in which it is demonstrated. Wenger's summation is richly evocative in contrasting Western museum collections of sacred art from other cultures with the originating contexts from which that art has been displaced:

The Western mind-dreary, apprehensive and exhausted by the chaotic intellectual stock exchange-inclines to retire from this apocalyptic carnival of values into the "simple and hearty" (as some think) world of fable, legend and myth. Resenting tenseness and sterility of monetary ways of life and linear thought, Western man carries his hunger into libraries and galleries, in whose glassy showcases are laid out the exploits of civilizations. Here linger dethroned, humiliated, effaced gods and their now stale insignia of sacred force and transcendent status. Anthropomorphized vessels of God's own glory and gloom, they are heaven's own tormented and disowned sons and daughters, attesting to man's likeness to his creator (74).

Wenger's summation is itself correlative with a strand of thought from Western observers of the growth of Western museums like the Louvre in Paris and the British Museum in London through the acquisitions of artefacts plundered through conquest in foreign, often non-Western cultures. Duncan presents this perspective in a compelling manner that resonates strongly with Wenger's stand. Referencing Elizabeth Gilmore Holt's The Triumph of Art for the Public, she describes the18th century German writer Johann Wolfgang von Goethe as deeply enthused by the development of what was then the novelty 
represented by the culture of the museum but was also appalled at the strategy of building museum collections through plunder, represented by the French emperor Napoleon Bonaparte's

systematic gathering of art treasures from other countries and their display in the Louvre as trophies of conquest. Goethe saw that the creation of this huge museum collection depended on the destruction of something else, and that it forcibly altered the conditions under which, until then, art had been made and understood. Along with others, he realized that the very capacity of the museum to frame objects as art and claim for them a new kind of ritual attention could entail the negation or obscuring of other, older meanings (431).

In contrast to the attenuation of value Wenger saw in the museum culture's divorcing of sacred art from its organic context, Wenger, with her Yoruba collaborators, in what became known as New Sacred Art, created shrines in the sacred Osun forest in Nigeria's Yorubaland, which, as she depicts these creations in A Life with the Gods in their Yoruba Homeland:

lie open without declaring themselves... a bridge between gods and the human perceptive imagination, in order to create themselves anew in the image of anyone's own spiritual demands Wine ferments only in the barrel; so sacred force ripens, secluded in the heart of matter.[ Our shrines and sculptures are like ] winebarrels which seclude the god's identity so that it can once again ferment into some primal manifestation (138).

Falola moves on from this focus on explicit sacred space as the privileged site of sacred encounter which the starting point of his reflections shares with Wenger's thought, to advocating sacred space as generated through the encounter between the religious image and the human mind. He thereby responds through his image theory and praxis to the epistemic disjointedness in terms of which classical African thought has been engaged with in the Western academy, a problematic reconfiguration of which the populating of Western museums with plundered African artefacts was part of this process of the recreation of African thought through a Western lens.

Falola does not advocate a wholesale return to classical African shrine culture but a new visually activated, mentalistic orientation in which the shrine emerges at the intersection of the human mind and sacred art, incidentally developing a reflective practice active in Hindu, Buddhist and Western esoteric image epistemology and their metaphysical roots, belief systems and their associated practices marginalized within the global dominance of central 
orientations in Western culture. He describes the process through which this conjunction between concrete religious form and its mental transposition takes place:

[Art, particularly the sacred art constituting ritual archives, generates an] epistemology that leads to a series of long conversations on human behaviour and interpersonal relationships in society [and possibly, as with the Sri Yantra, on the integration of self, society, the non-human terrestrial world and the cosmos]. An image moves you towards the spiritual and religious... there is an aesthetic idea living within it, allowing for texts on cultures, forms and styles (922).

He introduces the contemplative logic in terms of which this experience occurs:

While gazing without talking, you create the text, saying something, creating what Nietzsche calls an 'army of metaphors'. [A process that] generates a wide range of imaginations, and thought systems (922).

Falola's summation on this evocative process may be better understood through comparison with Kant's reflections on aesthetics in A Critique of the Power of Judgement as translated by James Creed Meredith:

[By] an aesthetic idea I mean that representation of the imagination which induces much thought, yet without the possibility of any definite thought whatever, i.e., concept, being adequate to it, and which language, consequently, can never get quite on level terms with or render completely intelligible. In a word, the aesthetic idea is a representation of the imagination, annexed to a given concept, with which, in the free employment of imagination, such a multiplicity of partial representations are bound up, that no expression indicating a definite concept can be found [thus allowing] a concept to be supplemented in thought by much that is indefinable in words, and the feeling of which quickens the cognitive faculties (145).

Kant's perception is itself enriched in comparison with Michael Faux and S. J. Gates's observations in "Adinkras: A Graphical Technology for Supersymmetric Representation Theory" that "The use of symbols to connote ideas which defy simple verbalization is perhaps one of the oldest of human traditions( 2)." Illustrating how the stimulation of symbols work in enabling knowledge without exhausting their own evocative depths, an understanding 
related to Falola's dramatization of the evocative force of an Esu figurine, Kant further elaborates:

[Some images give] the imagination an incentive to spread its flight over a whole host of kindred representations that provoke more thought than admits of expression in a concept determined by words. They furnish an aesthetic idea, which serves the above rational idea as a substitute for logical presentation, but with the proper function, however, of animating the mind by opening out for it a prospect into a field of kindred representations stretching beyond its ken (144).

Falola describes the contemplative process of engaging in imaginative dialogue with a work of art, referring specifically to a figurine of Ėșù: "What originally appears as a small wooden object opens up a vastness of knowledge, its edges become borderless, its existence acquires a force" (922). He depicts the details of contemplative engagement with the Esu figurine:

We are forced to move into the orbits of knowledge in which all component parts of the body become signifiers as ojú Ėșù becomes different from etí Essù, okó Esṣù, ògo Ėșù, and inú Ėșù [ ears of Ėṣu, penis of Ėṣù, forehead of Esșù, the inwardness of Èșù]. Each unit is semi-autonomous but aggregated to gbogbo ara Ėșù [the totality of Ėșù's being] in another layer of meaning. Add Ėșù pípè [perhaps Ėșù as embodiment of totality, the owner of all spaces, interior and exterior] yet another meaning. Like your own orí [the head as analogue of the immortal essence of the self, embodying its ultimate possibilities], that of Ėșù is also the zone of intelligence and emotions. All his calculations and miscalculations reside here. You can see orí Ėșù, with ògo Ėșù, as fronting multiple ideas. Attributes, then, derive from ojú Èșù, eté Esṣù, imú Ėșù [eyes, ears and nose of Èșù] , all connected with personal foibles and destiny. You must trigger your own wisdom and strength to deal with orí Essùu, and as you do, your own orí begins to breakdown into a series of components as that of ogbộn (wisdom) oròmùgọ (foolishness). You draw in your "bowel," to rely on ogbọ́n inú [inward wisdom or wisdom as an inward transmutation of cognitive elements]. Your eyes must work well, to recall your inner essence as in ojú inú [inward vision, inward perception, a movement beyond corporeal or basic perception to penetration to the essential qualities of phenomena beyond their more obvious qualities], and on your perceptions, ojú ọnà [the "eye of the mind", perception as a mental activity]. Should you be confused, look for an ẹnu àgbà (elder's wisdom) [wisdom of maturity expressed through speech] for guidance. And following the conversation, your inú ("stomach") [inwardness, 
internal nature, essential being as different from appearances] becomes the point of validation as in inú e bàjẹ (you are sad) [ literally- your insides, your interior, your mind as a demonstration of your inner life, is distorted, upset or unhappy ] inú e dùn (you are happy) [ your mind and emotions as the expressions of your inward nature are enjoying a pleasant feeling] , and inú e bu (you are damn stupid) [ literally-your inward state is in bad condition] (922-3).

This imaginative encounter mediated through the work of art representing the deity develops a visceral force generating intimacy of deity and contemplative:

The thought that you express to yourself and to others moves you back to the Essù image. Its force becomes a part of you. Whether you hate or like Essù, the image is activated. In the process, you must generate text around the image, expressing your religiosity, philosophy, and opinions....We are no longer dealing with the aesthetic of difference, as in looking at objects in the British Museum in London and looking at Ėșù in the National Museum, Alẹșinlọyé at İbàdàn or the Ėșù in the Heritage Museum of the University of İbàdàn...Eșù has entered your mental system, active in your conversation with yourself and others. Your thought is a text, on the physical world, on the afterlife, on mythologies, on religions, and more ( (922).

He sums up the impact of the experience:

One image of Ėșù tells us about social and cultural issues, portrayal of multiple and ambivalent ideas, representations of hybridity, discourse on difference, perception, semiotics, and religion. The Esṣù image, coupled with all other objects as well as all texts, and the entire ritual archives lead us to the indigenous intellectuals and their epistemologies. Combined, they deal with the invisible realities of knowledge, as in witchcraft. But they complicate the visible ones, as in all forms of epistemologies. An artistic production becomes a body of knowledge at various levels- political, cultural, and social. The Ėșù image transfers you to the understanding of culture and society; what is left of the past; and how the past is reformed, deformed, transmogrified, ordered, and reordered. The past may even be disappearing and that image affirms it (922-3). 


\section{Conclusion}

There are few things as satisfying as reading another writer articulate ideas similar to those you have long worked with as your deepest convictions and most intimate practices, but have not been able to organize, talk less express, with the comprehensiveness and clarity as the writer has done. Reading such a writer, your own thinking is magnified in robustness as theirs complements yours and yours enriches theirs, conceptions in one achieving fuller articulation through encounter with the other, seamless convergences creating a synergistic whole in which the sum is greater than its parts. That has been my experience with studying Toyin Falola's "Pluriversalism" and "Ritual Archives" essays in the Reader, these essays being central works of Falola as a philosopher of the humanities. Reading his sweeping and incisive analysis, years of aspiration and effort in my cognitive journey are illuminated in ways that excavate their logic, bringing to the surface ideas one has deeply internalized, but, which, before now, existed as inadequately reflexive rationalizations in one's theoretical landscape.

Reading "Pluriversalism" and "Ritual Archives", I am moved by discovering ideas I have long conceived and lived by but have never been able to express in the sweeping scope made more powerful by analytical acuity, in which Falola expresses them. I am particularly struck by his reflections on the need to rethink the disciplinary foundations and structures of ideational navigation in terms of which classical African cognitive systems are studied. Can they be explored in terms of a vantage point enriched by their own epistemic and metaphysical foundations? Can the forms of rationality they embody be placed in fruitful dialogue with the forms of rationality evident in Western thought, the dominant cognitive system unavoidable in its pervasiveness, its humanistic significance in its focus on unaided reason vital even as sensitivity to its negative deployment and limitations are fundamental to critically taking advantage of it, particularly as one seeks to engage with non-Western cognitive systems?

These questions are critical for me on account of my scholarly and practical explorations across various cognitive systems and perceptual strategies from various cultures and within various sub-cultures within dominant cultures, from Western magic to Benin nature spirituality and Hinduism. These investigations have enabled various self-publications as well as academic publications and a range of perceptual experiences best summed up for me by Babatunde Lawal and John Annechukwu Umeh's summations, in "Àwòrán: Representing the Self and its Metaphysical Other in Yoruba Art" and After God is Dibia: Igbo Divination, Cosmology and Sacred Science in Nigeria of Yoruba and Igbo Afa theories of perception respectively. 
They depict these ideas on perception as ranging from conventional to unconventional cognitive forms, from sensory perception to such fundamentals as critical thinking and imagination to such unconventionalities as extra sensory perception and witchcraft and perception of cosmic unity, a conception correlative with Falola's description of ritual archives as constituting and shaping knowledge about the "visible and invisible world [about] forces that breathe and are breathless" (913).

While I have been working with similar ideas in my individual bodies of work, Falola's perspective is that of a bird soaring above the creative landscape, its keen eye aggregating possibilities similar to those which I have engaged with in terms of distinctive expressions, his synthesizing intelligence transmuting the particular to the general and unfolding the general into the particular, unfurling a tapestry of myriad, interlinked possibilities, integrating potential that is then unfurled, breaking open an ideational consolidation to reveal a schematically organized universe of possibilities, a grain of sand, a tightly woven condensation of myriads, split open to reveal the cosmos, "In the heart of a minute particle of dust/is present a vast scroll/as large as the three thousand fold world/and on this scroll is recorded all things without exceptions/in this world system of three-thousand fold multi-thousand worlds" ( Gomez, 1995), invoking an image from the Buddhist Avatamsaka Sūtra similar to another from the English poet William Blake's "Auguries of Innocence" on seeing the world in a grain of sand.

\section{Bibliography}

Abimbola, Wande. An Exposition of Ifa Literary Corpus. Oxford: Oxford UP Nigeria, 1976. . Ifa Divination Poetry. New York: Nok, 1977.

Abiodun, Rowland. Yoruba Art and Language: Seeking the African in African Art. Cambridge: Cambridge UP, 2014.

Adéẹkọ́, Adéléké. https://www.facebook.com/adeleke.adeeko/ posts/10207910281435384. Facebook. 30 October 2017. Accessed 11/6/2018. Adepoju, Oluwatoyin Vincent. "Cosmological Permutations: Joseph Ohomina's Ifá Philosophy and the Quest for the Unity of Being”. Facebook Note of Friday 20th May 2016.

https://www.facebook.com/notes/oluwatoyin-vincent-adepoju/cosmological-permutations-joseph-ohominas-ifa-philosophy-and-the-quest-for-th e-u/10153612717949103/ Accessed 11/6/2018.

"Orality and the Metaphysics of Language in Yoruba Thought”. Facebook Note of Friday 20th May 2016. https://www.facebook.com/notes/oluwatoyin-vincent-adepoju/ 
orality-and-the-metaphysics-of-language-in-yorubathought/10153615682214103/ Accessed 11/6/2018.

"Orality and the Metaphysics of Language in Yoruba Thought 2: From Ife to Bamako, Delhi,Athens, Jerusalem,Berlin:Questions Arise". https://www.facebook.com/notes/ oluwatoyin-vincent-adepoju/orality-and-the-metaphysics-of-language-inyoruba-thought-2-from-ife-to-bamakode/10153616860119103/ Accessed $11 / 6 / 2018$.

"Rethinking Ifá: From Classical to Post-Clas-

sical Geometries 1: The Ifá Vectors of Moyo Okediji”. Facebook Note of 7th May 2016. https://www.facebook.com/notes/oluwatoyin-vincent-adepoju/rethinking-ifa-from-classical-to-post-classical-geometries-1-the-ifavectors-of-/10153359029869103/ Accessed 11/6/2018.

. Edited. "Ifá/Afa/Efa/ Fa, Science and Comparative Scholarship". Scribd.https://www.scribd.com/document/172364640/ Ifa-Afa-Efa-Fa-Science-and-Comparative-Scholarship Accessed 11/6/2018. . "Wole Soyinka's Art as a Psychological, Spiritual and Philosophical Resource". Facebook Note of 20 April 2015.

https://www.facebook.com/notes/oluwatoyin-vincent-adepoju/wole-soyinkas-art-as-a-psychological-spiritual-and-philosophical-resource/10152806772244103/ Accessed 11/6/2018.

"Contemplation as a Means of Creativity and Empowerment in the Work of Wole Soyinka: Void Meditation: Theory and Method. Post of 31 May 2011 at Cognitive Diary blog. https:// ifastudent-cognitivediary. https://ifastudent-cognitivediary.blogspot. com/2011/05/contemplation-as-means-of-creativity.html?view=mosaic\&fbclid=IwAR2omVB5IG1S6HXd MIqw0asZYtWzjDB1KfsDCaoc2QBYq szxCm9jhdlSA Accessed 11/6/2018.

. "Esu to the Mahavidyas: Integrating Contraries through Ideas and Art from Orisa to Tantric Cosmology" https:// www.facebook.com/notes/oluwatoyin-vincent-adepoju/esu-to-themahavidyasintegrating-contraries-through-ideas-and-art-from-orisa-to-/10153724224499103/ Facebook Note of Tuesday, 17 April 2018. Accessed 11/6/2018.

Alamu, Femi et al, "A Comparative Study of Ifa Divination and Computer Science", (IJITR) International Journal of Innovative Technology and Research, Volume 1, Issue 6, 2013, 524-528.

Alighieri, Dante, The Divine Comedy: Inferno, Purgatorio, Paradiso. (First published, in Italian, 1472). Translated by Robin Kirkpatrick.London: Penguin, 2013. 
Aristotle. The Metaphysics, translated by W.D.Ross in The Works of Aristotle. Vol.1.Edited by W. D. Ross. Chicago: Encyclopedia Britannica, 1952. 495-626.

Avatamsaka Sūtra, quoted in Luis O. Gomez. "The Whole Universe as a Sūtra," in Buddhism in Practice, ed. Donald S. Lopez, Jr. Princeton: Princeton U. P., 1995.108-9.

Ba, Ahmadou Hampate. Kaidara: A Fulani Cosmological Epic from Mali. Translation and Interview with Ba by Daniel Whitman. Washington: Three Continents Press, 1988.

Bazin, Germain. The Museum Age. New York: Universe Books, 1967.

Bediako, Kwame. "African Theology" in The Modern Theologians: An Introduction to Christian Theology in the Twentieth Century. Edited by David Ford. 2nd edition. Oxford: Wiley-Blackwell, 1997.

Blake, William. "Auguries of Innocence"(First published 1863) from Oxford Anthology of English Literature Volume II : 1800 To the Present. Edited by Frank Hollander and John Kermode. Oxford: Oxford UP, 1979.

Budge, Wallis. The Book of the Dead: The Papyrus of Ani in the British Museum; the Egyptian Text with Interlinear Transliteration and Translation, a Running Translation, Introduction. London: British Museum, 1895.

Brooks, Renfrew. The Secret of the Three Cities: An Introduction to Hindu Sakta Tantrism. Chicago: University of Chicago UP, 1990. The Texts and Traditions of Hindu Sakta Tantrism in South India. Albany, NY: SUNY Press, 1992.

Craig, Edward. Philosophy: A Very Short Introduction. Oxford: Oxford UP, 2002.

Dragon Rouge. "Philosophy", https://www.dragonrouge.net/english/philosophy.html Accessed 11/6/2018.

Donovan, Leo. "Living into Mystery: Karl Rahner's Reflections on his 75th Birthday", America: The Jesuit Review. January 02, 2018. https://www. americamagazine.org/faith/2018/01/02/living-mystery-karl-rahners-reflections-his-75thbirthday?fbclid=IwAR0DW4OQju7ECEX_219Pq1oSo0diXI2N923M1 Uoks2a2gsBrC0uCthUOoU Accessed 11/6/2018.

Dasgupta, Surendranath. History of Indian Philosophy Vol.1. Delhi: Motilal Banarsidass, 1975.

Drewal, Margaret Thompson and Henry John Drewal. “An Ifá Diviner's Shrine in Ijebuland" African Arts, Volume 16.2, 1983, 60-100.

Duncan, Carol. "The Art Museum as Ritual" in The Art of Art History: A Critical Anthology.

Edited by Donald Preziosi. Oxford: Oxford UP, 2009.424-433.

Falola, Toyin. The Toyin Falola Reader. Austin: Pan African University, 2018. 
Fatunmbi, Awo Fa'lokun, "Obatala:Ifá and the Chief of the Spirit of the White Cloth". https://www.scribd.com/document/47061087/OBATALA-Ifa-andthe-Chief-of-the-Spirit-of-the-White-Cloth-EDITED-AND-FORMATTED. Accessed 11/6/2018.

Foucault, Michel. The Order of Things: An Archaeology of the Human Sciences (First published in French, 1966) London: Routledge, 2002. . Madness and Civilization: A History of Insanity in the Age of Reason. (First published in French, 1961) New York: Random House, 1988. Faux, Michael and S. J. Gates. "Adinkras: A Graphical Technology for Supersymmetric Representation Theory" in Physical Review D: Particles and Fields 71(6), 2005.

Fortune, Dion. Applied Magic. London: Thorsons, 1997.

Galembo, Phyllis. Divine Inspiration: From Benin to Bahia. New York: Athelia Henrietta Press; 2nd edition, 1998.

Hawking, Stephen. A Brief History of Time: From the Big Bang to Black Holes. London: Bantam, 1988.

Herman, Arnold. The Illustrated to Think Like God: Pythagoras and Parmenides: The Origins of Philosophy. Las Vegas: Parmenides Publishing, 2004.

Holt, Elizabeth Gilmore, Edited. The Triumph of Art for the Public: The Emerging Role of Exhibitions and Critics. Washington: Decatur House Press, 1980.

Iliffe, Robert. Newton: A Very Short Introduction. Oxford: Oxford UP, 2007.

Irele, Abiola. "The African Scholar". Transition. 51.1991. 56-69.

Jeyifo, Biodun. "Abiola Irele: The Scholar as Critic" in Perspectives on Nigerian Literature, 1700 to the Present. Vol. 1. Edited by Yemi Ogunbiyi. 130-4.

Kant, Immanuel. Critique of Practical Reason.( First published in German, 1788) Translated by Mary Gregor. Cambridge: Cambridge UP, 2015.

. A Critique of the Power of Judgement. Translated by James Creed Meredith. Oxford: Oxford UP, 2009.

Khanna, Madhu. Yantra: The Tantric Symbol of Cosmic Unity. London: Thames and Hudson, 1994.

Kübler-Ross, Elizabeth. On Death and Dying, London: Routledge, 1969.

Kuhn, Thomas. The Structure of Scientific Revolutions (1st edition) Chicago: University of Chicago Press, 1962.

Lawal, Babatunde. "Äwòrán: Representing the Self and its Metaphysical Other in Yoruba Art" The Art Bulletin, Vol. 83, No. 3. 2001, 498-526.

Lear, Jonathan. Aristotle: The Desire to Understand, Cambridge: Cambridge UP, 1988.

Lovecraft, Howard Philips. The Call of Cthulhu and Other Weird Stories. London: Penguin, 2016. 
ries. London: Penguin, 2001. . The Thing on the Doorstep and Other Weird Sto. The Dreams in the Witch House and Other Weird Stories. London: Penguin, 2004.

Longe, Olu. Ifa Divination and Computer Science. Inaugural lecture, University of Ibadan, December 22, 1983.

Milton, John. Paradise Lost. 2nd edition. London: S. Simmons, 1674.

Ohomina, Joseph. Personal communication.

Olomo, Aina. A post of 2nd August 2010 at the USAAfrica Dialogues Series Google Group. Under the subject "Esoteric Knowledge and Power in the Orisa Tradition". https://groups.google.com/d/msg/yorubaaffairs/pZrVqt-14Do/3e5SxEIAEqAJ Accessed

$11 / 6 / 2018$.

Orangun, Adegboyeya. Destiny: The Unmanifested Being. Ibadan: African Odyssey, 1998.

Orofino, Giacomella. "The Great Wisdom Mother and the Gcod Tradition” in Tantra in Practice. Edited by David Gordon White. Princeton: Princeton UP, 200. 396-416.

Otto, Rudolph. The Idea of the Holy. ( First published in German, 1917) Oxford: Oxford UP,

1958.

Regardie, Israel. The Tree of Life: A Study in Magic. (First published 1932) Newburyport: Weiser, 200.

Soyinka, Wole. Myth, Literature and the African World. Cambridge: Cambridge UP, 1990.

Season of Anomy. London: Arena, 1988.

. Death and the King's Horseman. New York: Norton, 2002.

. The Credo of Being and Nothingness. Lagos: Spectrum, 2003. The Man Died. London: Rex Collings, 1972.

Sri Devi Khadgamala Stotram. Translation and Commentary by Shakti Saddhana Group. 2006.

“Theology". Encyclopaedia Britannica, 1971.

Thompson, Robert Farris. Face of the Gods: Art and Altars of Africa and the African Americas. New York: Museum for African Art, 1993.

Tolkien, John Ronald Ruel. The Lord of the Rings: The Fellowship of the Ring, The two Towers and The Return of the King. London: George Allen and Unwin, 1954. . The Silmarillion. London: George Allen \& Unwin|, 1977.

Umeh, John Annechukwu. After God is Dibia: Igbo Divination, Cosmology and Sacred Science in Nigeria. London: Karnark House, 1997 
Van Eck, Caroline. Art, Agency and Living Presence: From the Animated Image to the Excessive Object. Leiden: Leiden University Press, 2015.

Vansina, Jan. Oral Tradition. A Study in Historical Methodology (Translated from the French by H. M. Wright). London: Routledge \& Kegan Paul, 1965.

Waite, Renée B. African Concepts of Energy and their Manifestations through Art. MA thesis, College of the Arts of Kent State University, 2016.

Westfall, Richard. Never at Rest: A Biography of Isaac Newton. Cambridge: Cambridge UP, 1981.

."Isaac Newton". Encyclopaedia Britannica, 1992. 931-935.

Wenger, Susanne. "Review of Harold Courlander's Tales of Yoruba Gods and Heroes" in Research in African Literatures, Vol. 7, No. 1, 1976. 74-76.

Wenger, Susanne and Gert Chesi. A Life with the Gods in their Yoruba Homeland. Wörgl: Perlinger, 1983. 